\title{
MANAGEMENT OF THE BOVINE TUBERCULOSIS DIAGNOSTIC IN ROMANIAN FARMS, IN THE LIGHT OF THE MULTIDRUG-RESISTANT TUBERCULOSIS EMERGENCE
}

\author{
FLORICA BĂRBUCEANU ${ }^{1,2 \#, ~ D A N I E L A ~ S T A M A T E ~}{ }^{1,2 *}$, STELIAN BĂRĂITĂREANU ${ }^{2 \#,}$ \\ MARIA IONESCU ${ }^{1}$, GABRIEL PREDOI ${ }^{2}$ \\ ${ }^{1}$ Institute for Diagnosis and Animal Health, 63 Dr. Staicovici D. Nicolae Street, 050557, Bucharest, Romania \\ ${ }^{2}$ University of Agricultural Science and Veterinary Medicine, Faculty of Veterinary Medicine, 105 Splaiul Independentei, \\ 050097, Bucharest, Romania
}

*corresponding author: stamate.daniela@idah.ro

${ }^{*}$ Authors with equal contribution.

Manuscript received: May 2019

\begin{abstract}
Tuberculosis (TB) is still a public health concern in numerous countries. Livestock can plays an important role in the global control of TB and, consequently, the prevention of tuberculosis in farm animals is an important goal. This study shows the relevance of the diagnostic of the infections produced by Mycobacterium spp. in Romanian slaughtered cattle and consider the opportunity of antimycobacterial susceptibility testing in a veterinary laboratory. Phenotyping and genotyping of the Mycobacterium isolates between 2015 and 2016, revealed 567 strains of M. tuberculosis var. caprae and 22 strains of $M$. tuberculosis var. bovis. These data support the risk of TB emergence in cattle herds and the human population with $M$. tuberculosis var. caprae.
\end{abstract}

\section{Rezumat}

Tuberculoza (TB) continuă să fie o problemă de sănătate publică în numeroase țări. Șeptelul poate juca un rol important în controlul global al tuberculozei, iar prevenirea tuberculozei în fermele de animale este un obiectiv major. Acest studiu prezintă diagnosticul de laborator al infecțiilor cu Mycobacterium spp. la bovinele din România și analizează oportunitatea introducerii testului de sensibilitate la antimicobacteriene în laboratorul veterinar. Tipizarea izolatelor de Mycobacterium din perioada 2015 - 2016 a stabilit că 567 tulpini erau M. tuberculosis var. caprae și 22 M. tuberculosis var. bovis. Aceste date susțin riscul emergenței tuberculozei bovine și umane cu M. tuberculosis var. caprae.

Keywords: Mycobacterium, bovine tuberculosis, veterinary laboratory diagnostic

\section{Introduction}

Despite the important progress achieved by the European Union (EU) in the battle with tuberculosis (TB), this disease is still a public health threat for several countries, with 55,337 humane cases reported in 2017 by the $31 \mathrm{EU}$ and European Economic Area (EEA) countries, of which $72.10 \%$ were newly diagnosed [32]. In the same year, Romania reported 14,000 cases and one of the highest EU/EEA notification rates of tuberculosis in the 0 - 4 year-olds groups [32]. Moreover, Romania has the highest EU/EEA incidence of tuberculosis in humans, representing $25 \%$ of the tuberculosis load [33] and it is one of the WHO European Region's 18 high-priority countries for tuberculosis control [34].

In light of all this data, which covers only tuberculosis in the human population, any action designed to prevent, diagnose and manage infections with tuberculous and non-tuberculous mycobacteria in domestic animals; it is a valuable achievement for the global plan to eradicate TB.
Mycobacterium tuberculosis complex has several variants and a wide host range, each of these causing tuberculosis mainly in the host species: M. tuberculosis var. bovis in cattle, other bovid species, or humans, $M$. tuberculosis var. caprae in goats, $M$. tuberculosis var. microti in voles and other rodents, $M$. tuberculosis var. pinnipedii in marine mammals, M. tuberculosis var. mungi in mongooses, and M. tuberculosis var. orygis in oryxes (antelope species). However, most M. tuberculosis variants are generally capable of causing human disease, mainly among immunocompromised individuals [23]. The TB clinical form depends on the various factors (e.g., strain virulence, the host immune status, and the route of entry of the pathogen) [3, 13]. Livestock can play an important role in the spreading of several $M$. tuberculosis strains and, consequently, the prevention of tuberculosis in animals (e.g., bovine) become one of the most important actions in tuberculosis control. Bovine tuberculosis (BTB) is a zoonotic disease which causes significant economic losses due to a high cost of the eradication programs and trade restriction 
on live animals, meat, milk, and other products of animal origin [17, 24]. All of these are completed by public health threats: BTB is one of the seven neglected zoonotic diseases $[11,30]$. Studies on the best BTB preventive actions recommend the covering of at least following five actions: (1) Restricting the contact between cattle and wild reservoir (e.g., badger in the UK; bison, elk, and deer in the USA); (2) Managing of the cattle feed and water; (3) Banning of the infected animals' movement between herds; (4) Reducing of the risk from neighbouring herds; (5) Minimising of the infection risk from cattle manure [1, 2, 8, 12]. Vaccinating cows is banned in most countries in the world, enabling vets to continue to use the TST in BTB control programs. However, a novel vaccine and complementary TST to protect cattle against BTB have been recently proposed by Chandran et al. which could allow better protection of animals with the new BCG vaccine, while maintaining a novel DIVA skin test that will detect BTB [9].

In TB's diagnostic, laboratories play the central role by using a wide spectrum of techniques, most of them able to detect directly the etiological agent. The direct diagnostic can be done by the following methods: (a) Microscopy and culture; (b) Mycobacterial speciation by biochemical assays; (c) Mycobacterial antigen detection by monoclonal sera; (d) Analysis of lipid composition by chromatography; (e) Detection of DNA or RNA of mycobacterial origin. Indirect methods are based on the detection of $\operatorname{IgG}$ or $\operatorname{IgM}$ antibodies against mycobacteria or cellular immunity via skin tests [31].

In BTB's diagnostic, the World Organisation for Animal Health (OIE) recommends similar methods as those described in TB. The demonstration of acid-fast bacilli by microscopic examination, as a presumptive confirmation method, is followed by the mycobacteria isolation on selective culture media and their subsequent identification by cultural and biochemical tests or .nucleic acid recognition methods. Indirect methods include the TST (the prescribed test for international trade), the gamma-interferon assay (approved for use in several national programmes including in the European Union), the lymphocyte proliferation assay (not used for routine diagnosis) and the ELISA for measurement of humoral immunity [19]. Also, accurate and early diagnosis of TB should use conventional diagnostic methods in combination with modern molecular and immunological techniques [28].

The TB affects numerous domestic and wild mammalian and bird species, having major economic and public health implications $[6,15]$. In developed countries, BTB control is carried out by test and slaughter of infected animals, based primarily on the tuberculin skin test (TST) [28]. TST has some limitations and only one round of testing using standard interpretation may fail to detect $20-25 \%$ of infected cattle [10].
However, TST sensitivity can be increased by using the interferon-gamma blood test. Also, false negatives TST can occur as a consequence of the Johne's disease, immune-suppression of the animal, delayed hypersensitivity not yet developed, the terminal stages of TB infection and errors when carrying out the skin test $[10,19]$.

Many developed countries pay compensation to the farmers in the test-and-slaughter programs, perform also post-mortem examinations of the carcass, and implement control strategies in herds proved to be contaminated by using laboratory methods of diagnostic [19].

TB treatment is done only in the human population, while in animals it is not performed. By not treating BTB, resistance emergence of Mycobacterium tuberculosis variants against anti-TB drugs will be very low. However, the occurrence of drug-resistant tuberculosis (DRTB) became a real human threat, including a large spectrum of resistance, representing a red flag of burden TB even for developed low burden tuberculosis European countries [3].

In Romania, the surveillance, monitoring, and eradication of several cattle diseases are part of the national action plans and are carried out following the World Animal Health Organization (OIE) requirements [5, 7, 19, 26, 27].

In this study, we aimed to show the relevance of the diagnostic of the infections produced by Mycobacterium spp. in Romanian slaughtered cattle in the context of multi drug-resistant tuberculosis emergence.

\section{Materials and Methods}

\section{Biological samples}

The biological samples from this study were composed of lymph nodes from 590 bovines with the TST positive or inconclusive results, slaughtered for the confirmation of tuberculosis through laboratory examinations. The principles and recommendations of the European Union Reference Laboratory for Bovine Tuberculosis (Madrid, Spain) are applied throughout the diagnostic conduct. The more important rules applied to tuberculosis are Council Directive 64/432/EEC who defined the status officially free for tuberculosis in bovine herds; Regulation 852/2004 and Regulation $853 / 2004$ who establishes the procedures for the postmortem inspection at slaughterhouse [35-37].

\section{Morphopathological examination}

The lymph nodes were sliced at about $1-2 \mathrm{~mm}$, and the section surfaces examined very carefully for typical or suspicious lesions. The macroscopic appearance of the tuberculous lesions will be gray-white or yellowish nodules, not encapsulated, firm or hard, with a yellowish yellow centre, usually with calcifications. Microscopic examination and culture

Bacteriological exams were performed at the National Reference Laboratory for Bovine Tuberculosis (Institute 
of Diagnosis and Animal Health, Bucharest, Romania) in accord with Chapter 3.4.6. - Bovine tuberculosis of the OIE Terrestrial Manual 2018. Briefly, samples of lymph nodes collected from a bovine with positive or dubious results in the tuberculin tests were used to prepare direct smears stained with the Conventional Ziehl-Neelsen (ZN) method. The smears were performed from the caseous lymphadenitis lesions or the concentrated pathological material destined for culture and biological tests. Tissue specimens for culture were firstly homogenised using a mortar and pestle, decontaminated with an equal volume of $2-4 \%$ sodium hydroxide solution for 30 minutes at $37^{\circ} \mathrm{C}$ and then neutralized with a few drops of $10 \% \mathrm{HCl}$ or $5 \%$ oxalic acid in the presence of a colour indicator. The sediment was used for culture and microscopic examination. The sediment was inoculated on solid egg-based media Lowenstein-Jensen with sodium pyruvate, Malachite green and glycerol free, Middlebrook 7H10 or 7H11 with egg, Malachite green, bovine serum, oleic acid and albumin, and Herrold's egg yolk agar with sodium pyruvate. Cultures were incubated for a minimum of 8 weeks at $37^{\circ} \mathrm{C}$, with a weekly examination to detect growth.

The identity of the suspected cultures was confirmed by microscopic analysis to detect acid-alcohol-resistant bacilli and the phenotypic characteristics for differentiation of infrasubspecific $M$. tuberculosis variants. $M$. tuberculosis var. bovis is sensitive to thiophen-2carboxylic acid (TCH) hydrazide, isonicotinic acid hydrazide (INH), para-amino-salicylic acid and streptomycin; it is negative for niacin accumulation and nitrate reduction, and in the amidase test it is positive for urease and negative for nicotinamidase and pyrazinamidase. Histopathological examination

Routine histological processing steps were used for histopathological examination. Briefly, lymph nodes samples were fixed in 10\% Formalin (formaldehyde), the paraffin blocks were sectioned by using precision knives (microtome) at $3-5 \mu \mathrm{m}$ and the microscopic examination of slides were done after $\mathrm{ZN}$ staining. Guinea pig virulence testing (biotest)

Guinea pigs (young males of 250 - $300 \mathrm{~g}$ ) were subcutaneously inoculated with $0.5 \mathrm{~mL}$ inoculum obtained by free decanting the suspension (about 10 grams of pathological material in one volume of sterile physiological serum) and monitored daily up to 90 days. Two guinea pigs were used per sample. In the case of guinea pig death in the first days after inoculation, the necropsy, bacterioscopic or cultural examination was performed to isolate and identify the bacterium that caused the death of the animals, and the biotest was repeated using guinea pig pathological material. The study was conducted in the frame of Strategic Plan approved by Order no. 35/2016 of president of Central National Sanitary Veterinary and Food Safety Authority. Mice were housed at the Animal Facility of Faculty of Veterinary Medicine-Bucharest, authorisation number 277/2016, in groups of 2 to 6 individuals in isolated ventilated cages in a standardized environment $\left(22.5 \pm 1.5^{\circ} \mathrm{C}, 55 \pm 10 \%\right.$ relative humidity, $12 \mathrm{~h}$ light/dark cycle, 74 changes of air per hour), fed a standard rodent diet ad libitum and had free access to water.

Genotyping of Mycobacterium species/strains

For the identification and differentiation of M. tuberculosis var. bovis and var. caprae was used the GenoType MTBC test (Hain Lifescience, Germany). Assays were performed according to the manufacturer's instructions, previously described by Richter et al. (2003) [21]. Briefly, $10 \mu \mathrm{L}$ of bacterial culture grown on solid medium were suspended in $300 \mu \mathrm{L}$ ultrapure water, sonicated $5 \mathrm{~min}$, incubated 20 minutes at $95^{\circ} \mathrm{C}$, and 5 $\mu \mathrm{L}$ of the suspension was used in the PCR reaction with the Taq DNA polymerase in a final volume of $50 \mu \mathrm{L}$. Hybridization was performed at $45^{\circ} \mathrm{C}$ and $300 \mathrm{rpm}$ with an automated device (TwinCubator; Hain, Germany), in a volume of $20 \mu \mathrm{L}$ of the amplification product.

\section{Results and Discussion}

The macroscopic appearance of the lymph nodes exanimated for the tuberculosis lesions (gray-white or yellowish nodules, not encapsulated, firm or hard, with a yellowish yellow centre, with or without calcifications) revealed the presumptive macroscopically lesions of tuberculosis in $99.83 \%(589 / 590)$ cases (Figure 1).

In accord with OIE Terrestrial Manual [19], for all slaughtered cattle with the TST positive or dubious results, the presumptive diagnosis of infection with M. tuberculosis var. bovis was for all tissues with characteristic histological lesions, respectively: chronic granulomatous caseous-necrotising inflammatory process, mineralisation, epithelioid cells, multinucleated giant cells of the Langhans type and macrophages.

The microscopic examination of smears from clinical samples proved to be a relatively insensitive method of BTB diagnosis. These results are in accord with the general point of view which considers the smear microscopy with the light microscope able to detect only $\sim 60-70 \%$ of TB [29]. Several methods allow identification of mycobacterial species, ranging from biochemical typing to genotyping, but the gold standard test for the TBT confirmation is the cultivation of the organism on primary isolation medium followed by phenotypic or/and genotyping methods [19].

Phenotypic methods of mycobacteria identification took into consideration morphological characteristics, growth rates, growth temperature, pigmentation, and biochemical characteristics. On pyruvate-based solid medium, smooth and off-white (buff) colonies were classified as M. tuberculosis var. bovis. Also, those isolates were positive for urease and negative for nicotinamidase and pyrazinamidase. 


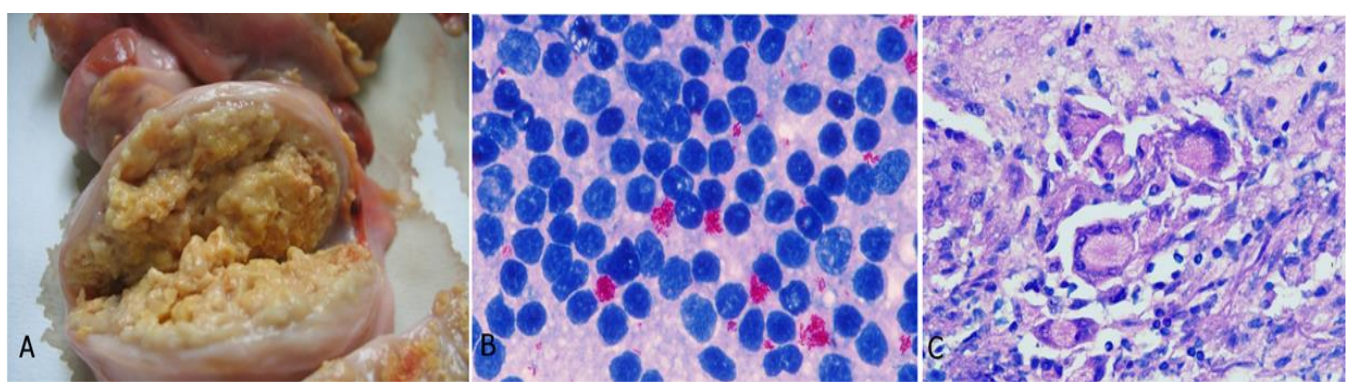

\section{Figure 1.}

The pathological aspect of bovine tuberculosis. A: chronic granulomatous caseous-necrotising inflammatory process in lymph node; B: acid-fast bacilli (AFB)-positive smear (ZN, x1000); C: multinucleate giant cells of the Langhans type (H\&E, x400)

Guinea pigs' experimental infection revealed 99.83\% (589/590) isolates with specific pathological results for $M$. tuberculosis complex: swelling of the regional lymph node, eventual abscess, and persistent ulcer. However, Guinea pig virulence testing did not allow differentiation of M. tuberculosis var. bovis and $M$. tuberculosis var. caprae. Guinea pigs are sensitive to experimental infection with the species of the
Mycobacterium tuberculosis complex and resistant to $M$. avium infection [26].

Phenotyping and genotyping of the Mycobacterium isolates between 2015 and 2016, revealed $567(96.10 \%)$ strains of $M$. tuberculosis var. caprae, $22(3.73 \%)$ strains of M. tuberculosis var. bovis and one $(0.17 \%)$ strain of $M$. avium subsp. avium (Table I).

Table I

Mycobacterium species and infraspecies isolated in Romania (Data recorded between 2015 and 2016 by Institute for Diagnosis and Animal Health, Bucharest, Romania)

\begin{tabular}{|c|c|c|c|c|c|c|c|}
\hline $\begin{array}{c}\text { Mycobacterium } \\
\text { species }\end{array}$ & \multicolumn{2}{|c|}{$\begin{array}{c}\text { Mycobacterium tuberculosis } \\
\text { var. bovis }\end{array}$} & $\begin{array}{c}\text { Mycobacterium tuberculosis } \\
\text { var. caprae }\end{array}$ & \multicolumn{2}{c|}{$\begin{array}{c}\text { Mycobacterium avium } \\
\text { subsp. avium }\end{array}$} & Total \\
\hline Year & 2015 & 2016 & 2015 & 2016 & 2015 & 2016 & \\
\hline No. of animals & 17 & 5 & 251 & 316 & 0 & 1 & $\mathbf{5 9 0}$ \\
\hline$\%$ & 2.88 & 0.85 & 42.54 & 53.56 & 0 & 0.17 & $\mathbf{1 0 0}$ \\
\hline
\end{tabular}

Considering the infraspecies of $M$. tuberculosis isolated in Romanian cattle with positive or dubious reactions at tuberculin skin tests between 2015 and 2016 (Figure 2), 64.86\% (382/589) were Romanian Spotted breed, 33.61\% (198/589) Holstein Friesian, and 1.53\% $(9 / 589)$ other breeds.
The analysis of infected animals by age categories revealed the highest value of infected cattle at the age group "12 - 50 months" with 50.76\% (299/589), followed by group " $>50$ months" with $27.00 \%$ $(159 / 589)$ and group “< 12 months" with $22.24 \%$ (131/589) (Figure 3).

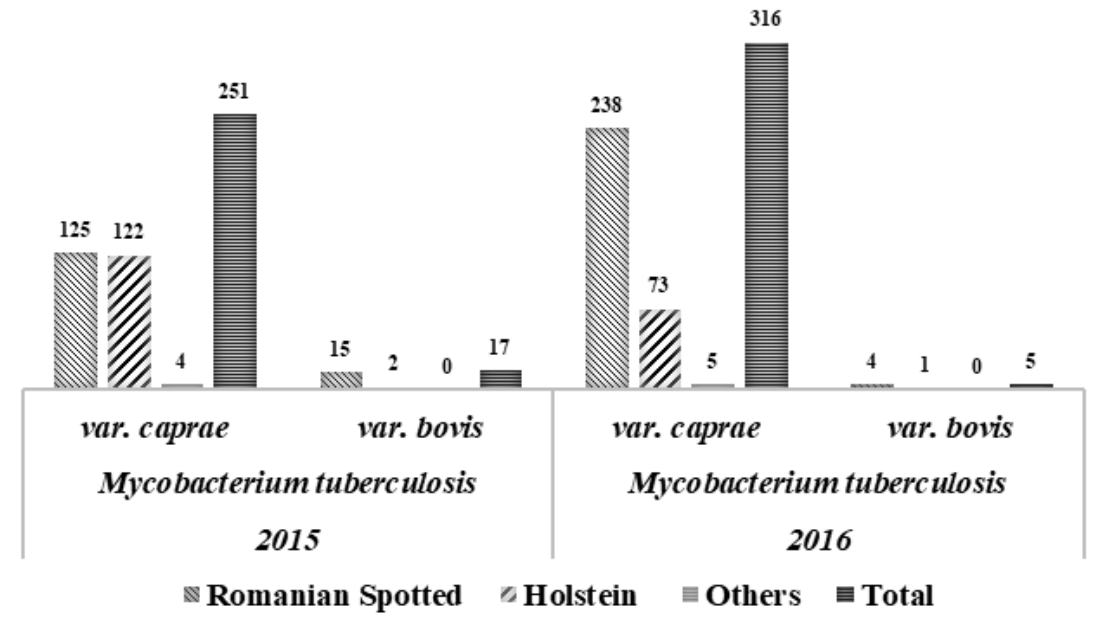

Figure 2.

Infraspecies of $M$. tuberculosis isolated in Romanian cattle with positive or dubious reactions at tuberculin skin tests, by breed categories (Data recorded between 2015 and 2016 by Institute for Diagnosis and Animal Health, Bucharest, Romania) 


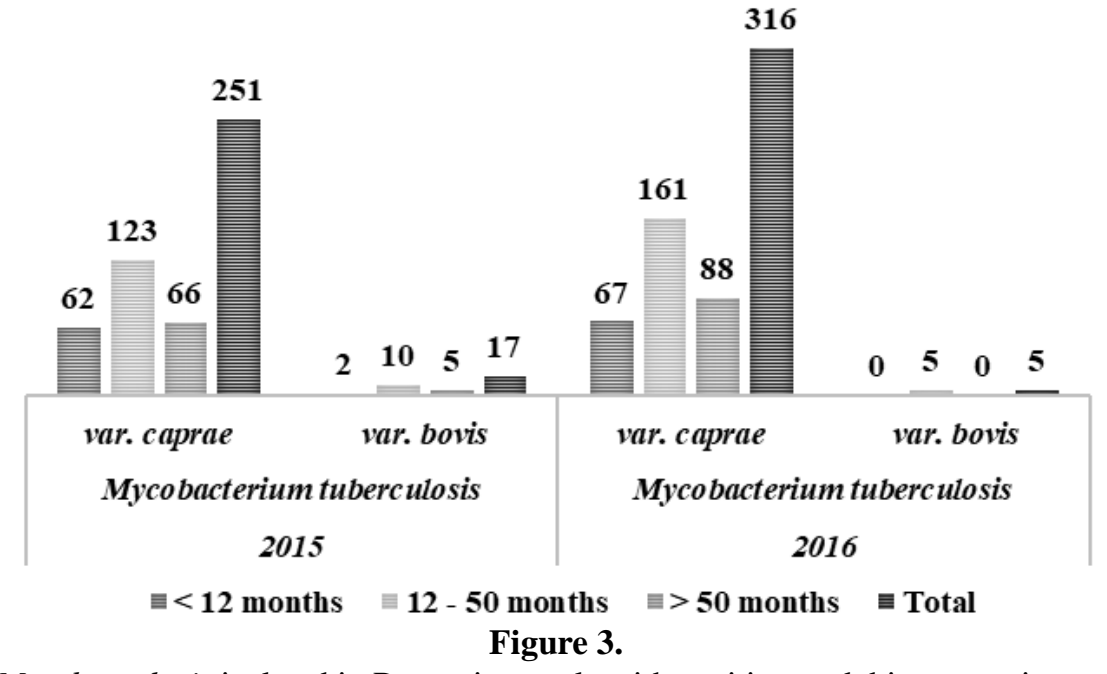

Infraspecies of M. tuberculosis isolated in Romanian cattle with positive or dubious reactions at tuberculin skin tests, by age categories (Data recorded between 2015 and 2016 by Institute for Diagnosis and Animal Health, Bucharest, Romania)

In our study, the GenoType MTBC assay proved to be a very useful tool in the rapid identification and differentiation of $M$. tuberculosis infraspecies with an easy-to-perform reverse hybridization assay. Similar results were reported by Richter et al. in their works with $M$. tuberculosis isolates in cultures obtained from clinical specimens [21, 22].

Concerning the lesions collected from the lymph node samples examined in this study, no difference has been found between the pathologic profiles of infections by $M$. tuberculosis var. caprae and $M$. tuberculosis var. bovis, both as typology and expression. In one laboratory the $M$. avium subsp. avium strain was isolated in a bovine, from a non-professional holding.

Increased number of M. tuberculosis var. caprae ( $\mathrm{n}=$ 567 ) in the lymph node samples originated from TST positive animals $(n=590)$ identified within the national eradication programs, from abattoir surveillance, support the risk of the emergence of this pathogen in cattle herds. This situation should concern the national and international authorities as long as $M$. tuberculosis var. caprae is a human pathogen [16] and consumption of unpasteurized dairy products from animals with lesions in the mammary glands is a public health risk [25].

Also, in the light of the recent studies that proved the ability of zoonotic variants of $M$. tuberculosis (bovis and caprae) to acquire antimicrobial resistance due to treatment of humans with TB $[4,14,18]$, the confirmatory diagnosis should include the antimicrobial resistance (AMR) profile of each strain not only in humane tuberculosis, but also in bovine tuberculosis. Considering the DR-TB as a serious threat to global control of TB [20], the detection of multi-drug resistance (MDR-TB), extensively drug resistance (XDR-TB) and totally drug-resistant (TDR) strains in the veterinary laboratory can prevent the emergence of zoonotic DR-TB.

\section{Conclusions}

Between 2015 and 2016, the Mycobacterium isolates from the Romanian cattle with positive or dubious reactions at tuberculin skin tests were $96.10 \%$ (567/ 590) M. tuberculosis var. caprae and $3.73 \%$ (22/590) M. tuberculosis var. bovis. The most affected breeds were Romanian Spotted (64.86\%, 382/589) and Holstein Friesian $(33.61 \%, 198 / 589)$, and most frequently reported at the " 12 - 50 months" age group $(50.76 \%, 299 / 589)$ and "> 50 months" age group $(27.00 \%$, (159/589). Considering the zoonotic risk of $M$. tuberculosis var. caprae and M. tuberculosis var. bovis, a more complete characterization of the isolates identified in the veterinary laboratory by the antimycobacterial susceptibility testing would be recommended. Also, it is necessary to further intensify the active surveillance measures for bovine tuberculosis, mainly in small dairy farms.

\section{Conflict of interest}

The authors declare no conflict of interest.

\section{References}

1. Agriculture and Horticulture Development Board, Protect your herd from TB: a review of the science, 2015, https://tbhub.co.uk.

2. APHIS, Questions and Answers: Preventing Bovine Tuberculosis, 2014, www.aphis.usda.gov.

3. Arghir OC, Pereira PMA, Rascu A, Dantes E, Borgazi E, Iliescu DM, Otelea MR, Cambrea SC, The impact of migrant tuberculosis on the chimioresistance pattern of antituberculosis drugs in a low burden tuberculosis European country. Farmacia, 2018; 66(3): 537-540.

4. Armstrong J, Christie P, Two cases of multidrug resistant Mycobacterium bovis infection in Scotland. Euro. Surveill., 1998; 2(37): pii=1159. 
5. Baraitareanu $\mathrm{S}$, Vidu L, The preventive medicine of bovine viral diarrhoea - mucosal disease in dairy farms: a review. Revista Romana de Medicina Veterinara, 2019; 29(2): 61-64.

6. Barbuceanu F, Popovici A, Diaconu C, Hotoiu C, Stamate D, Raita S, Denisan D, Predoi G, Histologycal researches on assessement of some staining histological methods used for diagnosis of bovine tuberculosis. Scientific works Series C. Veterinary Medicine, 2013; LIX(2): 145.

7. Barbuceanu F, Simmons M, Chaplin M, Diaconu C, Nicolae S, Raita S, Belu C, Predoi G, Conduct of diagnosis in the case of occurrence of bovine spongiform encephalopathy in Romania. Prion, 2015; 9(Supp.1): S12-S12.

8. Broughan J, Judge J, Ely E, Delahay RL, Wilson G, Clifton-Hadley RS, Goodchild AV, Bishop H, Parry JE, Downs SH, A review of risk factors for bovine tuberculosis infection in cattle in the UK and Ireland. Epidemiol Infect., 2016; 144(14): 2899-2926.

9. Chandran A, Williams K, Mendum T, Stewart G, Clark S, Zadi S, McLeod N, Williams A, Villarreal-Ramos B, Vordermeier M, Maroudam V, Prasad A, Bharti N, Banerjee R, Kasibhatla SM, McFaddenet J, Development of a diagnostic compatible BCG vaccine against Bovine tuberculosis. Sci Rep., 2019; 9: 1-11.

10. De la Rua-Domenech R, Goodchild AT, Vordermeier HM, Hewinson RG, Christiansen KH, CliftonHadley RS, Ante mortem diagnosis of tuberculosis in cattle: A review of the tuberculin tests, $\gamma$-interferon assay and other ancillary diagnostic techniques. Res Vet Sci., 2006; 81: 190-210.

11. Ereqat S, Nasereddin A, Levine H, Azmi K, AlJawabreh A, First-time detection of Mycobacterium bovis in livestock tissues and milk in the West Bank, Palestinian territories. PLoS Negl Trop Dis., 2013; 7(9): 1-8.

12. French General Directorate for Food, French National Bovine Tuberculosis Action Plan 2017-2022, 2018, http://agriculture.gouv.fr.

13. Golli AL, Nitu FM, Balasoiu M, Rascu S, Lungu MA, Dinescu SN, Ciobanu-Mitrache L, Glodeanu A, Vacaru M, Olteanu M, Microbiological profile and antibiotic resistance pattern of bacterial uropathogens among hospitalized patients. Farmacia, 2019; 67(1): 167-173.

14. Guerrero A, Cobo J, Fortun J, Navas E, Quereda C, Asensio A, Canon J, Blazquez J, Gomez-Mampaso E, Nosocomial transmission of Mycobacterium bovis resistant to 11 drugs in people with advanced HIV-1 infection. Lancet, 1997; 350: 1738-1742.

15. Krishna M, Gole S, Comparison of Conventional Ziehl-Neelsen Method in Tuberculous Lymphadenitis. J Citol., 2017; 34 (4): 188-192.

16. Kubica T, Rüsch-Gerdes S, Niemann S, Mycobacterium bovis subsp. caprae caused one-third of human $M$. bovis-associated tuberculosis cases reported in Germany between 1999 and 2001. J Clin Microbiol., 2003; 41: 3070-3077.

17. Le Roex N, Van Helden PD, Koets AP, Hoal EG, Bovine TB in livestock and wildlife: What's in the genes?. Physiol Genomics, 2013; 45: 631-637.

18. McLaughlin AM, Gibbons N, Fitzgibbon M, Power JT, Foley SC, Hayes JP, Rogers T, Keane J, Primary isoniazid resistance in Mycobacterium bovis disease: a prospect of concern. Am J Respir Crit Care Med., 2012; 186(1): 110-111.

19. OIE, 2018, Chapter 3.4.6. Bovine tuberculosis. In: Manual of Diagnostic Tests and Vaccines for Terrestrial Animals, 1058-1074, https://www.oie.int.

20. Prasanna A, Niranjan V, Classification of Mycobacterium tuberculosis DR, MDR, XDR isolates and identification of signature mutationpattern of drug resistance. Bioinformation, 2019; 15(4): 261-268.

21. Richter E, Weizenegger M, Fahr AM, Rüsch-Gerdes $\mathrm{S}$, Usefulness of the GenoType MTBC assay for differentiating species of the Mycobacterium tuberculosis complex in cultures obtained from clinical specimens. J Clin Microbiol., 2004; 42(9): 4303-4306.

22. Richter E, Weizenegger M, Rüsch-Gerdes S, Niemann S, Evaluation of genotype MTBC assay for differentiation of clinical Mycobacterium tuberculosis complex isolates. J Clin Microbiol., 2003; 41(6): 2672-2675.

23. Riojas, MA, McGough KJ, Rider-Riojas CJ, Rastogi $\mathrm{N}$, Hazbon $\mathrm{MH}$, Phylogenomic analysis of the species of the Mycobacterium tuberculosis complex demonstrates that Mycobacterium africanum, Mycobacterium bovis, Mycobacterium caprae, Mycobacterium microti and Mycobacterium pinnipedii are later heterotypic synonyms of Mycobacterium tuberculosis. Int J Syst Evol Microbiol., 2018; 68: 324-332.

24. Rodriguez-Campos S, Smith NH, Boniotti MB, Aranaz A, Overview and phylogeny of Mycobacterium tuberculosis complex organisms: Implications for diagnostics and legislation of bovine tuberculosis. Res Vet Sci., 2014; 97: 5-19.

25. Rodwell TC, Moore M, Moser KS, Brodine SK, Strathdee SA, Tuberculosis from Mycobacterium bovis in binational communities, United States. Emerg Infect Dis., 2008; 14: 909-916.

26. Stamate D, Barbuceanu F, Ionescu M, Popovici A, Vuta V, Predoi G, The management and the relevance of the diagnostic of the infections produced by Mycobacterium spp. in slaughtered bovine in Romania. J Biotechnol., 2018; 280(Supp.): S73-S74.

27. Stefan G, Danes D, Badea IA, Campeanu MV, Popp MC, Baraitareanu S, The usefulness of the somatic cell count indicator in the evaluation of mammary gland's health status in dairy cows. Revista Romana de Medicina Veterinara, 2019; 29(2): 41-44.

28. Teppawar RN, Chaudhari SP, Moon SL, Shinde SV, Khan WA, Patil AR, Zoonotic Tuberculosis: A Concern and Strategies to Combat, In: Basic Biology and Applications of Actinobacteria, IntechOpen, London, UK. 2018; 23-38.

29. Teran R, de Waard JH, Recent advances in the laboratory diagnosis of tuberculosis. EJIFCC., 2015; 26(4): 295-309.

30. Theon C, LoBue P, Enarson D, Kaneene J, de Kantor IN, Tuberculosis a re-emerging disease in animals and humans. Vet Ital., 2009; 45: 135-181.

31. Watt B, Rayner A. Gillan H. Mycobacterium. In: Colle JC, Fraser AG, Marion BP, Simmons A. eds. Mackie MacCartney, Practical Medical Microbiology. New York, Churchill Livingstone; 1996: 329-341.

32. WHO Regional Office for Europe/European Centre for Disease Prevention and Control. Tuberculosis surveillance and monitoring in Europe 2019 - 2017 
data. Copenhagen: WHO Regional Office for Europe; 2019.

33. WHO Regional Office for Europe/European Centre for Disease Prevention and Control. Review of the national tuberculosis programme in Romania, 10-21 March 2014. Copenhagen: WHO Regional Office for Europe; 2014.

34. WHO Regional Office, 2007. Plan to stop TB in 18 high-priority countries in the WHO European Region, 2007-2015. Copenhagen: WHO Regional Office for Europe; 2007, www.euro.who.int.
35. ***Council Directive 64/432/EEC of 26 June 1964 on animal health problems affecting intra-Community trade in bovine animals and swine, https://eur-lex. europa.eu.

36. $* * *$ Regulation (EC) No $852 / 2004$ of the European Parliament and of the Council of 29 April 2004 on the hygiene of foodstuffs, https://eur-lex.europa.eu.

37. $* * *$ Regulation (EC) No 853/2004 of the European Parliament and of the Council of 29 April 2004 laying down specific hygiene rules for food of animal origin, https://eur-lex.europa.eu. 